\title{
Evaluation of the Influence of the Use of Waste from the Processing of Rice in Physicochemical Properties and Biodegradability of PHB in Composites
}

\author{
Ana Paula Wünsch Boitt, Ivonete Oliveira Barcellos, Leila Denise Alberti, Doris Zwicker Bucci \\ Departamento de Química, Universidade Regional de Blumenau - FURB
}

\begin{abstract}
The high calorific value of rice husks has elevated its reuse as an energy source; however, the burning of these shells generates a waste ash from rice husk ash (RHA), which makes its disposal a concern. Despite advances, biodegradable polymers are not yet able to compete with those of traditional thermoplastics, which have lower production cost and higher performance. Based on this background, this paper studies the feasibility of reuse of RHA as filler in polymer matrices replacing the conventional filler. This study consists of applying different percentages of RHA in the formulation of polyhydroxybutyrate composite (PHB) and the use of talc (TA) for comparison purposes as conventional filler. The composites used in this assay were obtained by twin-screw extrusion and injection molding of the polymer plus the fillers under study. Physicochemical and biodegradability properties of the composites were evaluated. The composite PHB/RHA was superior in the biodegradability tests and the properties remain practically unchanged in the presence of the filler. Thus, composites with RHA are promising because they take an abundant residue combined with degradation capacity of the polymer, therefore reducing cost and the environmental impact.
\end{abstract}

Keywords: Rice husk ash, composites, PHB, talc, fillers.

\section{Introduction}

In materials selection, the durability in use and degradability after disposal are sought. On the other hand, biodegradable polymers are still not able to compete with traditional thermoplastic materials that meet the market demand especially due to low cost and superior performance $e^{[1]}$.

PHB (polyhydroxybutyrate) is a category of biodegradable polymer since it is produced through bacterial fermentation, usually by Alcaligenes genre microorganism, being synthesized under limited culture conditions. Alcaligenes eutrophus is the organism that is most widely used due to its reproduction rate and the accumulation of large quantities (up to $80 \%$ of dry weight) ${ }^{[2-4]}$. The PHB production on a large scale is still a relatively expensive process, mainly because of the process difficulties that due to their narrow processing conditions, since it is very instable near the melting point $\left(180^{\circ} \mathrm{C}\right)$; allied to high crystallinity providing high fragility ${ }^{[5]}$. These facts lead studies to improve these properties ${ }^{[6-8]}$.

Natural fibers and residues have been used successfully as filler trying to reduce costs and the environmental impact of plastics, generating composites with the same or better properties than the original polymer.

Companies that produce parboiled rice, burn the rice husk as an energy source, which generates the rice husk ash (RHA). The manufacture of materials using the RHA either as primary or as secondary component is an alternative to solve the problem of disposal of this ash in the environment and might create a product with higher added value ${ }^{[9,10]}$. The chemical component majority of the RHA is silica $\left(\mathrm{SiO}_{2}\right)$, at least $90 \%$ of the ashes composition ${ }^{[11,12]}$.
Alcantara used rice husk ash as additive to the lime in the production of soil-lime bricks and the results showed that the bricks met the standards required for components of masonry, regarding unconfined average compressive strength, individual strength and water absorption ${ }^{[13]}$.

Talc is a mineral with chemical theoretical composition of $31.7 \% \mathrm{MgO}, 63 \% \mathrm{SiO}_{2}$ and $4.8 \% \mathrm{H}_{2} \mathrm{O}$, used in the plastics industry as a filler and reinforcement. The main technological properties that make it widely used are: high thermal shock resistance, lightness, smoothness, high brightness, high lubricity and slip, high capacity to absorb oil and grease, low thermal and electrical conductivity, high surface area, chemical inertness and good retention as a filler, being used in the plastics industry as a filler and reinforcement ${ }^{[1,15]}$.

Replacements have been sought for the breakthrough of the plastics industry occur in a sustainable manner and one alternative found is the insertion of agroindustrial waste as filler in polymer matrices ${ }^{[16-18]}$.

The presence of RHA as matrix filler of PHB also showed favorable regarding the mechanical properties such as: impact resistance, hardness, flexural modulus and deformation in tension, as shown by Alberti et al. ${ }^{[19]}$.

The objective of these studies was to obtain and evaluate composites of polyhydroxybutyrate (PHB) using rice husk ash (RHA) as filler in different percentages, as well as the use of talc (TA) as conventional filler for comparison purposes. The properties of biodegradability and physico-chemical characteristics such as swelling, chemical stability and permeability to water vapor were evaluated, to provide a possibility of economy using RHA.

Corresponding author: Ivonete Oliveira Barcellos, Departamento de Química, Universidade Regional de Blumenau - FURB, Rua Antônio da Veiga, 140, Victor Konder, CEP 89012-900, Blumenau, SC, Brasil, e-mail: iob@furb.br 


\section{Experimental}

\section{Preparation of composites}

The materials to obtain the composites were the PHB and RHA. PHB, with molecular weight 115,000 g. $\mathrm{mol}^{-1}$, was obtained from sugarcane fermentation, and supplied by PHB Industrial S/A. The batch used was FE-159: PHB with $3.14 \%$ of the nominal content of estradiol valerate ${ }^{[11]}$. The rice husk ashes have been provided by the Juriti Cooperative (Massaranduba-SC) and talc was also supplied by PHB Industrial S/A.

Composites were prepared in the Laboratory of Biodegradable Polymers-UFSCAR-Federal University of São Carlos. The proportions of filler by weight in the PHB polymeric matrix was $5 \%, 10 \%, 15 \%$ of both, rice husk ash (RHA) and Talc (TA) of ( $\% \mathrm{w} / \mathrm{w})$. The composites were extruded in a co-rotating twin screw, 30:40 DRC model IF, brand IMACOM, thread 30mm, L/D 40. After extrusion, pellets were dried in circulating air oven at $60^{\circ} \mathrm{C}$ for a period of 24 hours, therefore for being injected the molded samples. The particle sizes of the components used were RHA 149-297 $\mu \mathrm{m}$ (100-50 mesh), TA $75 \mu \mathrm{m}$ (200 mesh) and PHB 600-1000 $\mu \mathrm{m}$ (30-18 mesh).

\section{Swelling index assay}

Four PHB samples and their composites were placed in drying oven at $100{ }^{\circ} \mathrm{C}$ to constant weight (referred to the dry samples (Ds)) and stored in desiccator for further study on swelling. These samples were immersed in distilled water ( $\mathrm{pH}$ 6.04) kept in oven at $30^{\circ} \mathrm{C}$ on predefined times. When taken from the water, the excess on the surface was removed with the aid of filter paper, and then weighed; this weight refers to the wet sample. The readings of weights were performed every 12 hours on the first day and every 24 hours until stabilization. The swelling index, I (\% w/w) was obtained considering the dry mass weight (Ds) and wet mass weight samples (Ws) through Equation 1:

$$
I(\%)=\frac{W s-D s}{D s} .100
$$

\section{Chemical stability assay}

Chemical stability test in acidic and alkaline aqueous solutions, organic solvents and neutral detergent was performed to verify the possibility of solubilization of some substances of the composite material to the fluid medium. The aim was to verify the possibility to use PHB as packaging. The resistance to solubility, using the gravimetric method, was evaluated based on the weight loss in order to estimate the chemical degradation ${ }^{[20]}$.

The samples of composites PHB/TA and PHB/RHA in quadruplicate have been identified and individually weighed. The samples were placed in drying oven at $100^{\circ} \mathrm{C}$ for 3 hours. After this period, they were transferred to a desiccator containing silica gel as a desiccant and, when stabilized at room temperature, they were weighed on an analytical balance. This cycle was repeated until constant weight (dry sample) which corresponds to the initial weight $\left(\mathrm{W}_{\mathrm{i}}\right)$.
Samples were placed into test tubes to analyze the chemical stability, identified and immersed in solutions of PA Acetone $\left(\mathrm{CH}_{3} \mathrm{COCH}_{3}\right) ; 95 \%$ Ethanol $\left(\mathrm{CH}_{3} \mathrm{CH}_{2} \mathrm{OH}\right)$; $10 \%(\mathrm{w} / \mathrm{v}) \mathrm{NaCl} ; 10 \%(\mathrm{v} / \mathrm{v}) \mathrm{H}_{2} \mathrm{SO}_{4} ; 10 \%(\mathrm{v} / \mathrm{v}) \mathrm{HCl} ; 1,5$, 10 , and $50 \%(\mathrm{w} / \mathrm{v}) \mathrm{NaOH}$, and neutral liquid detergent $(\mathrm{pH}$ 7.0 to 7.1). All reagents used were of VETEC brand, and the detergent was made by Adhetec Chemistry Ltda. The tubes with the samples remained in the oven for 24 hours at $30^{\circ} \mathrm{C}$. After that, they were removed from the solution, washed with distilled water and placed in drying oven at $100{ }^{\circ} \mathrm{C}$ to constant weight. This constant mass refers to the samples degraded after the test, final weight $\left(\mathrm{W}_{\mathrm{f}}\right)$. The chemical stability was obtained by calculating the percentage of weight loss from the values of $\mathrm{W}_{\mathrm{i}}$ and $\mathrm{W}_{\mathrm{f}}$, according to Equation 2 below:

$$
\% \text { Loss }=\frac{W_{i}-W_{f}}{W_{i}} .100
$$

\section{Water vapor permeability}

The permeability of the films of pure polymer and composites was determined by the method of diaphragm cell, where a permeation cell containing the film of the pure polymer and composites, with a thickness of $0.15 \mathrm{~mm}$, and silica gel as drying agent is subjected to controlled temperature and humidity conditions within a desiccator, according to the ASTM E96-13 ${ }^{[21]}$. Within time the films absorb humidity making it possible to measure the water vapor permeability (WVP) through Equation 3:

$$
W V P=\frac{H_{2} O_{(g) \cdot X}}{A}
$$

Where: WVP $=$ Water vapor permeability $\left(g . \mathrm{mm} . \mathrm{cm}^{-}\right)$; $\mathrm{H}_{2} \mathrm{O}(\mathrm{g})=$ Amount in grams of water absorbed by the sample;

$\mathrm{X}=$ Film thickness $(\mathrm{mm})$;

$\mathrm{A}=$ Contact surface area of the sample $\left(\mathrm{cm}^{2}\right)$.

\section{Biodegradation assay in natural environment}

Samples of PHB and their composites after being identified one by one were buried in soil of the experimental field of the Agronomy course UNOESC - Universidade do Oeste de Santa Catarina in the city of Campos Novos. The assay was performed in quintuplicate and a set of samples taken every 30 days up to 210 days after starting the test. The weight of samples were measured on an analytical scale and compared to the initial mass, thus calculating the percentage of weight loss $(\mathrm{w} / \mathrm{w})^{[4,20]}$. The rainfall conditions data for monitoring the experimental period (eight months) was obtained from Epagri-Campos Novos.

\section{Results and Discussion}

\section{Swelling index assay}

There was no significant change in the water $\mathrm{pH}$ during the swelling test, ranging from 6.04 to 5.97 after samples removal. The samples exhibited a negligible change in swelling index with the immersion time (maximum $0.8 \%$ ), the balance being reached within 15 days. 
It was observed that the samples with rice husk ash (RHA) showed higher water absorption depending on time when compared to PHB or PHB/TA (Figure 1). Except for $5 \%$ of RHA, the swelling index was virtually the same: $0.55 \%$ for PHB and $0.50 \%$ for PHB/RHA.

The explanation for greater absorption by the rice husk ash compared to PHB and talc in composites 10 and $15 \%$ of RHA is the ash particle size considerably larger than the talc particle size. This fact allows the formation of voids, greater than 5\% RHA in polymer matrix of composites, facilitating water penetration and absorption by the ash grains because of its porous nature, evidenced in studies in which rice husk ash was used as adsorbent material for dyes ${ }^{[22,23]}$.

\section{Chemical stability assay}

The PHB samples were more chemically resistant in 24-hour period, when comparing to its composites, and those that had talc as filler had higher chemical stability if compared to rice husk ash.

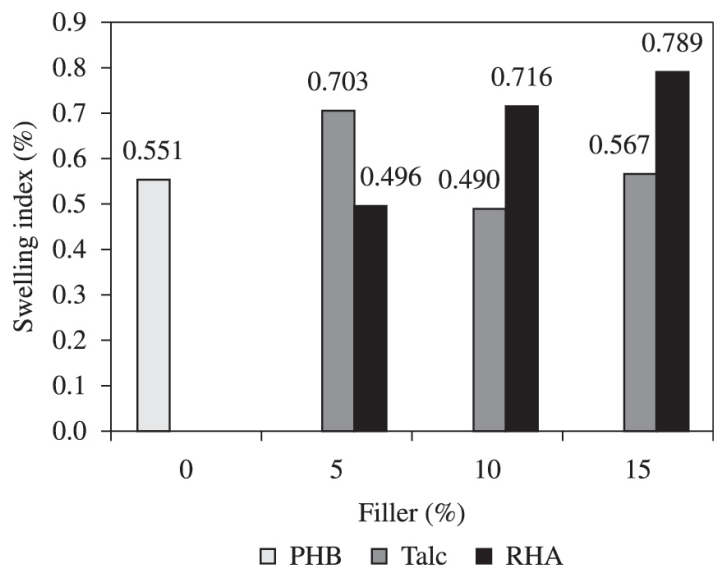

Figure 1. Swelling index for PHB and its composites at $30{ }^{\circ} \mathrm{C}$.
PHB/TA Figure 2a, showed lower resistance in alkaline solutions of $10 \%$ and $50 \% \mathrm{NaOH}$, increasing with filler content. While the PHB/RHA showed lower stability in $10 \% \mathrm{H}_{2} \mathrm{SO}_{4}$ solution and those alkali regarding the weight loss, as shown in Figure 2b. In the $50 \% \mathrm{NaOH}$ solution, composites containing $15 \%$ of fillers have very close values of weight loss for both the talc (5.95\%) and RHA (5.89\%).

Despite composites being less resistant than the pure polymer, the difference was not very significant. For PHB/ TA, the mass loss did not exceed $5.95 \%$ in 24 hours and in PHB/RHA the maximum value was $6.89 \%$ in the same period. As expected, as PHB as composites chemically degrade more significantly in alkaline medium. This is due the filler that been formed by silicates that have acid $\mathrm{pH}$, easily reacting with alkaline solutions ${ }^{[24]}$; and because of the increased rate of hydrolytic degradation of $\mathrm{PHB}$, this phenomenon is known as basic hydrolysis or saponification $^{[20]}$.

Since the samples immersed in the solution of sodium hydroxide $50 \%(\mathrm{w} / \mathrm{w})$ were those with lower chemical resistance, the stability test was also applied to this solution. It was monitored at different times to verify what was the behavior of the composite over a longer period of time, 30 days. As it can be in Figure 3, the weight loss increases progressively overtime, except for $\mathrm{PHB} / 15 \%$ RHA. It was observed that in 28 days there was a mass reduction of only $10 \%$, at $\mathrm{PHB} / 15 \%$ RHA, on the other hand the mass reduction as high as $80 \%$ in absence of RHA.

Regarding to chemical stability at longer period, the composites containing 15\% RHA and 15\% TA have shown to possess greater chemical stability if compared to pure $\mathrm{PHB}$ when immersed in $\mathrm{NaOH}$ solution $(50 \% \mathrm{w} / \mathrm{w})$. However, there is an inversion; the PHB/TA when exposed in longer time is more able to degrade than the PHB/ RHA. This mean that, in $24 \mathrm{~h}$ there was lower chemical degradation in polymeric matrix and higher solubilization of the fillers. As seen in Figure 2, the RHA, that has high percentage of silica $\left(\mathrm{SiO}_{2}\right)$, this has an acid character, being more reactive

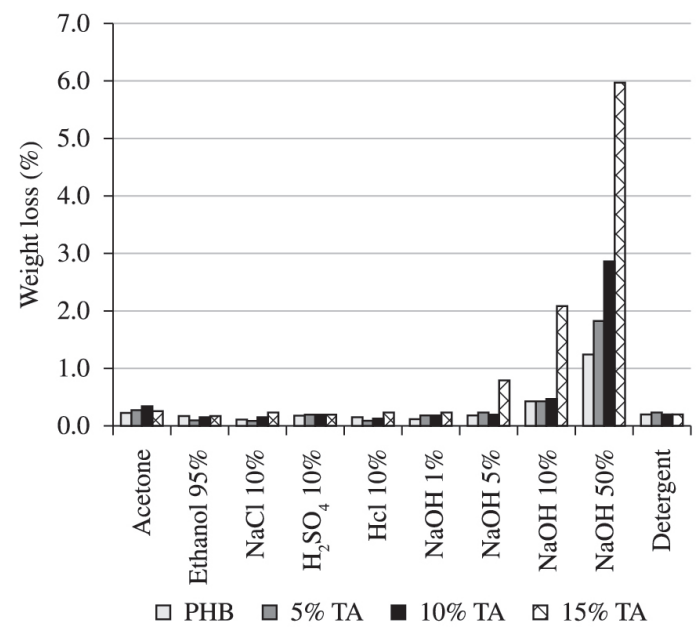

(a)

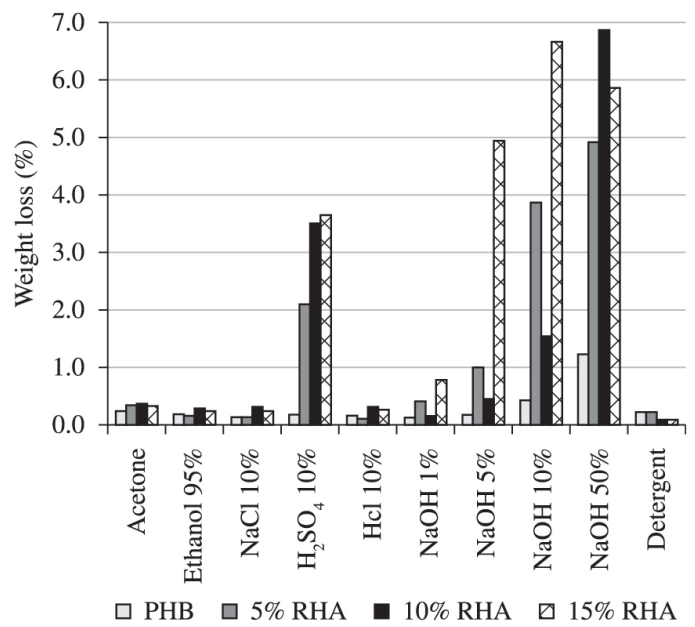

(b)

Figure 2. Percentage of weight loss in relation to chemical agents among composites in 24-hour period: (a) PHB/TA and PHB (b) PHB/ RHA and PHB. 


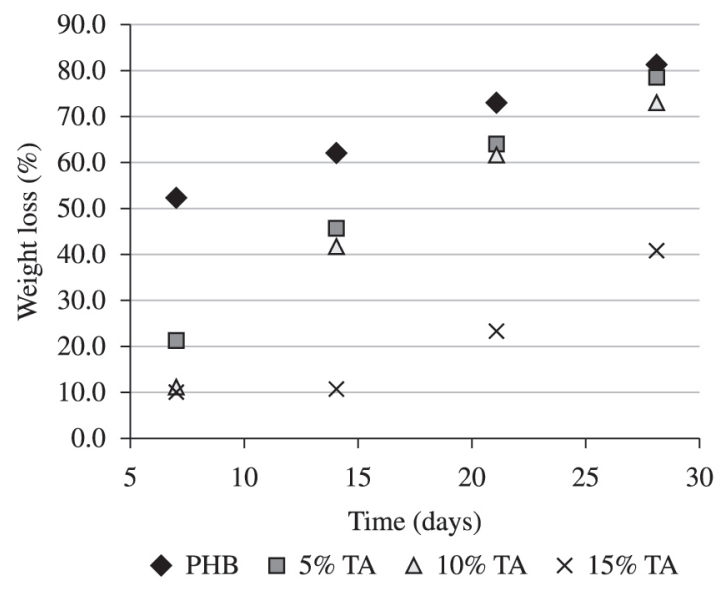

(a)

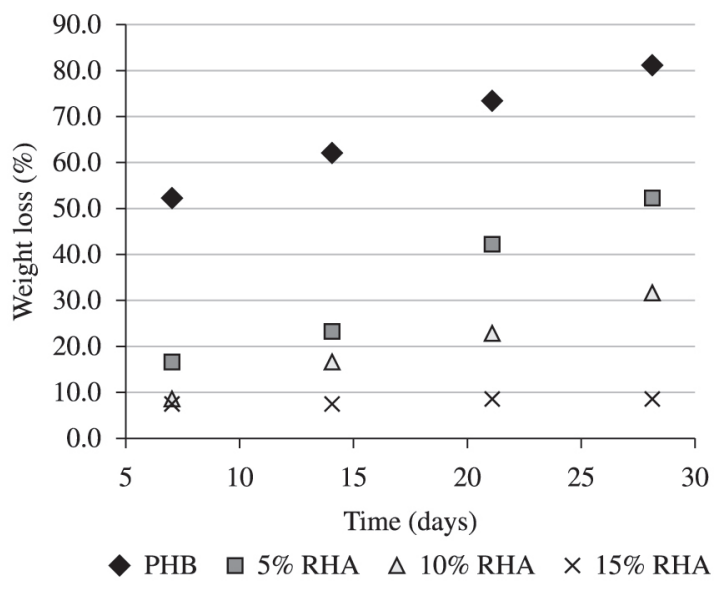

(b)

Figure 3. Percentage of weight loss within time in 50\% NaOH solution: (a) PHB/TA and PHB, (b) PHB/RHA and PHB.

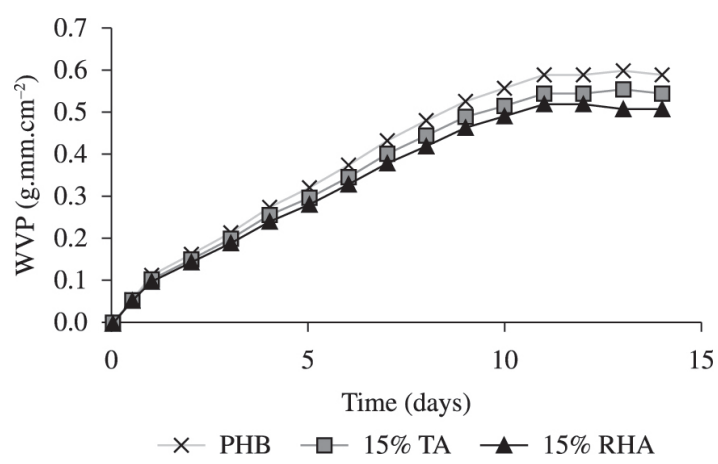

Figure 4. Water vapor permeability of PHB and its composites.

in alkaline solution than $\mathrm{PHB} / \mathrm{TA}$, and even more compared with PHB. The PHB/TA was more able to degrade than $\mathrm{PHB} / \mathrm{RHA}$ because probably the ashes $\left(\sim 90 \% \mathrm{SiO}_{2}\right)$ were first leached to solution than talc $\left(\sim 60 \% \mathrm{SiO}_{2}\right)$.

Nevertheless, in longer time what happen is the opposite, what can be explained due the higher polymer degradation and not just the solubulization or leaching of the fillers to the solution. Therefore, what can be affirmed is that the PHB degradation is gradative in longer time and the leaching occur on the initial time of the chemical degradation, clarifying the greater stability of the composites. After all, they have lower percentage (w/w) of polymer and lower weight loss than PHB.

\section{Water vapor permeability}

The water vapor permeability is the rate of water vapor transmission per unit area through the film of known thickness, induced by a pressure gradient between two specific surfaces of temperature and specified relative humidity ${ }^{[1]}$. Figure 4 shows the results obtained after 15 days of monitoring the water vapor test with $\mathrm{PHB}$ and PHB samples containing 15\% TA and RHA.

The weight gain of permeation cells progressed exponentially until 10 days thereafter starts the equilibrium to be reached. Films of PHB and composites of $15 \%$ of filler showed that permeability values were very close in conditions of $97-99 \%$ humidity at $20^{\circ} \mathrm{C}$. The introduction of TA or even the RHA in the matrix of PHB does not interfere with water vapor permeability.

Films should provide a barrier that prevents or hinders the contact between external environment and the product inside, once many products are susceptible to deterioration due to moisture gain as dehydrated foods, medicines, powdered detergent, among others that agglomerate with increased humidity ${ }^{[25]}$. In some other foods such as fresh meat, cheese, frozen foods, fresh vegetables, for example, a low permeable film may be indicated when loss of humidity should be avoid ${ }^{[26]}$.

\section{Biodegradation assay in natural environment}

The samples that showed more degradation in soil were composites of rice husk ash, and the $\mathrm{PHB} / 15 \%$ RHA had the highest percentage of degradation, $2.32 \%(\mathrm{w} / \mathrm{w})$ in 120 days as can be seen in Figure 5a.

Regarding to talc composites, as shown in Figure 5b, they presented lower weight loss, not exceeding $1.84 \%$ (w/w) (PHB/15\% TA) in 120 days. This low degradability in both types of composites and samples of PHB may be explained from the metrological report of Epagri-Campos Novos, which recorded low rainfall index in that period, not being conducive to proliferation of microorganisms on the ground.

When the test completed 150 days, samples were subjected to a period of more 60 days buried ( 210 days) to observe whether there would be change in behavior as shown in Figure 5. The degradation of a polymer depends on its nature and the environmental conditions, which may vary from exposure to abiotic factors such as temperature, humidity, $\mathrm{pH}$, active microorganisms and the surface area of the sample $e^{[4,27,28]}$. The samples were buried in a soil where there is no-till soybeans, $\mathrm{pH} 5,7$; mainly the samples of 150-210 days were closer to soybean planting and with little sunlight. Those facts should have caused a lower biodegradation of composites in that period, due to 


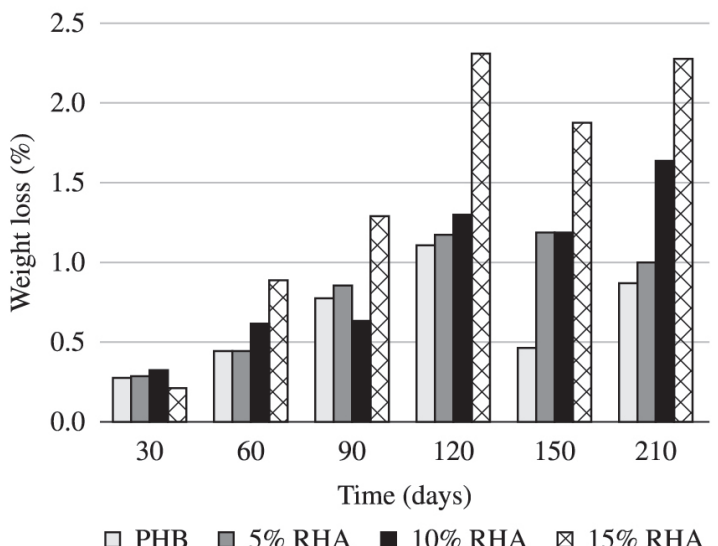

(a)

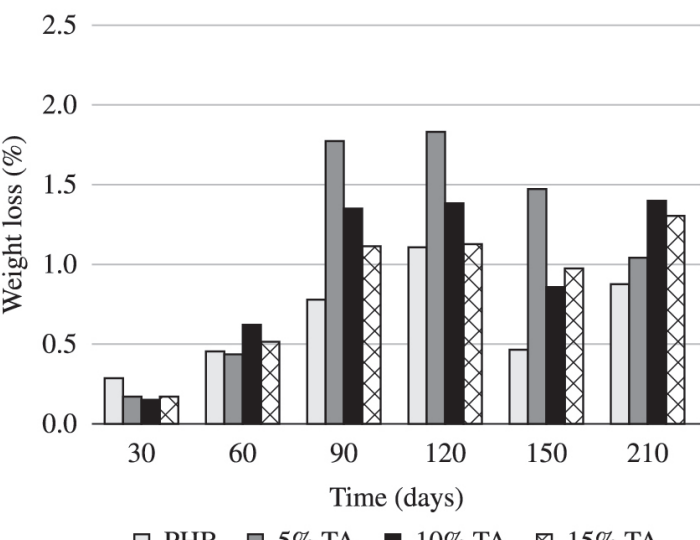

$\square$ PHB $\square 5 \% \mathrm{TA} \square 10 \% \mathrm{TA} \otimes 15 \% \mathrm{TA}$

(b)

Figure 5. Percentage of loss weight of samples after contact with the ground: (a) PHB and PHB/RHA, (b) PHB and PHB/TA.

the factors that were not the most favorable, including the soil $\mathrm{pH}(5,7)$.

In general the samples had low biodegradation mainly due to the factors that were not the most favorable, including the soil $\mathrm{pH}(5,7)$. This must have inhibited the activity of the microorganisms responsible for biodegradation, besides not promoting the hydrolysis of the ester, which is a very important step in the biodegradation ${ }^{[29]}$.

The PHB/RHA had higher biodegradation than PHB probably due to leaching of the fillers to the ground providing greater exposure area of the polymer and greater contact surface for the action of microorganisms. The PHB/ TA has showed the same behavior but the biodegradation rate was lower than ashes, because talc has smaller particle size which promoted a composite with lower porosity.

\section{Conclusion}

The results of the study showed that with the addition of up to $15 \%$ of RHA as filler of PHB is very promising, as there was no negative effect on the properties of the evaluated composites. When compared to PHB, composites showed small variations or the same values, in the swelling index, water vapor permeability, biodegradation and chemical stability.

According to the results, it is possible to conclude that PHB/RHA composite can make the use of PHB polymer economically viable. It also can provide a suitable environmental solution to the high volume of waste generated by parboiled rice industry, the RHA.

\section{Acknowledgements}

Pipe Article 170, the PHB Industrial S/A for donating the materials, the Laboratory of Biodegradable Polymers/ UFSCAR along with the support of Professor José A. M. Agnelli for collaboration and the UNOESC for the space provided to perform the experiments of biodegradation "in situ".

\section{References}

1. Falcone, D. M. B. \& Agnelli, J. A. M. - Polímeros., 17, p.5 (2007).

2. American Society for Testing Materials - ASTM - " $D-883$ 12 Stardard Terminology for Relating to Plastics", ASTM International, West Conshohocken, PA (2012).

3. Rosa, D. S.; Penteado, D.F. \& Calil, M. R. - Polímeros., 15, p.75 (2000).

4. Bucci, D. Z.; Tavares, L. B. B. \& Sell, I. - Polym. Test., 26, p.908 (2007). http://dx.doi.org/10.1016/j. polymertesting.2007.06.013.

5. Jesus, R. C. - "Processamento e caracterização de biocompósitos de PHB com fibras naturais de coco e sisal acetiladas e não-acetiladas", Dissertação de Mestrado, Universidade Estadual de Campinas, Brasil (2008).

6. Machado, M. L. C.; Pereira, N. C.; Miranda, L. F.; Terence, M. C. \& Pradella, J. G. C. - Polímeros., 20, p.65 (2010). http:// dx.doi.org/10.1590/S0104-14282010005000011.

7. Krishnaprasad, R.; Veena, N. R.; Maria, H. J.; Rajan, R.; Skrifvars, M. \& Joseph, K.- J. Polym. Environment., 17, p.109 (2009). http://dx.doi.org/10.1007/s10924-009-0127-x.

8. Macedo, J. S.; Costa, M. F.; Tavares, M. I. B. \& Thiré, R. M. S. M. - Polym. Eng. Sci., 50, p.1466 (2010). http://dx.doi. org/10.1002/pen.21669.

9. Della, V. P.; Kühn, I. \& Hotza, D. - Quim. Nova., 24, p.778 (2001). http://dx.doi.org/10.1590/S0100-40422001000600013.

10. Neto, E. R. - "O estado da arte do uso da cinza de casca de arroz", SOCIESC, Santa Catarina (2007).

11. Alberti, L. D. - "Propriedades Físico-químicas e Mecânicas de Compósitos de Poli(hidroxibutirato) PHB”, Dissertação de Mestrado, Universidade Regional de Blumenau, Brasil (2013).

12. Bezerra, I. M. T.; Souza, J.; Carvalho, J. B. Q. \& Neves, G. A. - Rev. Bras. Eng. Agrícola Ambiental., 15, p.639 (2011).

13. Alcantara, M. A. M.; Santos, L. P.; Lima, D. C.; Zegantini, A. A. S. \& Akasaki, J. L. - Rev. Eletrônica de Eng. Civil., 3, p.1 (2011).

14. Luz, A. B. \& Lins, F. F. - "Rochas e minerais industriais: usos e especificações", in: Talco, cap.29, Ivan F. Pontes and Salvador Luiz M. de Almeida (eds.), Cetem, Rio de Janeiro (2005).

15. Coelho, J. M. - "Perfil do Talco Pirofilita e agalmatolito", J.Mendo Consultoria, Belo Horizonte (2009). 
16. Mello, C. C.; Thiré, R. M. S. M. \& Costa, M. F. - “Caracterização de compósitos poli(3-hidroxibutirato) e pó de coco acetilado", COPPE/UFRJ, Rio de Janeiro (2010).

17. Macedo, J. S. - "Desenvolvimento de biocompósitos à base de polihidroxibutirato e resíduos de processamento de fibras de casca de coco", Tese de Doutorado, Universidade Federal do Rio de Janeiro, Brasil (2010).

18. Alfaro, E. F. - "Estudos da Utilização de cinzas de casca de arroz como carga em matriz de polipropileno e do efeito da radiação ionizante sobre este compósito", Dissertação de Mestrado, Instituto de pesquisas energéticas e nucleares, Brasil (2010).

19. Alberti, L. D.; Souza, O. F.; Bucci, D. Z. \& Barcellos, I. O. - Mater. Sci. Forum., 775-776, p.557 (2014). http://dx.doi. org/10.4028/www.scientific.net/MSF.775-776.557.

20. Carashi, J. C.; Ramos, U. M. \& Leão, A. P. - Acta Scientiarum., 24, p.1609 (2002).

21. American Society for Testing Materials - ASTM - "E 96M13 - Standard test method for water vapor transmission of materials", ASTM International, West Conshohocken, PA (2013).

22. Chiarello, L. M.; Blosfeld, A. M.; Giovanella, R. F. \& Barcellos, I. O. - Quim. Têxtil., 91, p.54 (2008).
23. Barcellos, I. O.; Giovanella, R. F.; Chiarello, L. M. \& Blosfeld, A. M. - Dynamis., 15, p.1 (2009).

24. Kalapathy, U.; Proctor, A. \& Shultz, J. - Bioresour. Technol., 73 , p.257 (2000). http://dx.doi.org/10.1016/S09608524(99)00127-3.

25. Sarantópoulos, C. I. G. L.; Oliveira, L. M.; Padula, M.; Coltro, L.; Vercelino, R. M. \& Garcia, E. E. C. - "Embalagens Plásticas Flexiveis - Principais Polímeros e Avaliação de Propriedades", CETEA/ITAL, Campinas (2002).

26. Sobral, P. J. A. \& Ocuno, D. - Brazilian J. Food Tec., 3, p.11 (2000).

27. Vinhas, G. M.; Almeida, Y. M. B.; Lima, M. A. G. A. \& Santos, L. A. - Quim. Nova., 30, p.1584 (2007). http://dx.doi. org/10.1590/S0100-40422007000700016.

28. Buzarovska, A.; Grozdanov, A.; Avella, M.; Gentile, G. \& Errico, M.- J. Appl. Polym. Sci., 114, p.3118 (2009). http:// dx.doi.org/10.1002/app.30867.

29. Rosa, D. S.; Chui, Q. S. H.; Pantano Filho, R. \& Agnelli, J. A. M. - Polímeros., 12, p.311 (2002).

Received: Oct. 18, 2013

Revised: Apr. 30, 2014

Accepted: May 26, 2014 